\title{
Enhanced biosurfactant production through cloning of three genes and role of esterase in biosurfactant release
}

\author{
Kamaljeet Kaur Sekhon ${ }^{1 *}$, Sunil Khanna ${ }^{2}$ and Swaranjit Singh Cameotra ${ }^{3}$
}

\begin{abstract}
Background: Biosurfactants have been reported to utilize a number of immiscible substrates and thereby facilitate the biodegradation of panoply of polyaromatic hydrocarbons. Olive oil is one such carbon source which has been explored by many researchers. However, studying the concomitant production of biosurfactant and esterase enzyme in the presence of olive oil in the Bacillus species and its recombinants is a relatively novel approach.

Results: Bacillus species isolated from endosulfan sprayed cashew plantation soil was cultivated on a number of hydrophobic substrates. Olive oil was found to be the best inducer of biosurfactant activity. The protein associated with the release of the biosurfactant was found to be an esterase. There was a twofold increase in the biosurfactant and esterase activities after the successful cloning of the biosurfactant genes from Bacillus subtilis SK320 into E.coli. Multiple sequence alignment showed regions of similarity and conserved sequences between biosurfactant and esterase genes, further confirming the symbiotic correlation between the two. Biosurfactants produced by Bacillus subtilis SK320 and recombinant strains BioS a, BioS b, BioS c were found to be effective emulsifiers, reducing the surface tension of water from 72 dynes/cm to as low as 30.7 dynes $/ \mathrm{cm}$.

Conclusion: The attributes of enhanced biosurfactant and esterase production by hyper-producing recombinant strains have many utilities from industrial viewpoint. This study for the first time has shown a possible association between biosurfactant production and esterase activity in any Bacillus species. Biosurfactant-esterase complex has been found to have powerful emulsification properties, which shows promising bioremediation, hydrocarbon biodegradation and pharmaceutical applications.
\end{abstract}

\section{Background}

Biosurfactants are surface active agents of microbial origin. They have the unique property of lowering the interfacial tension between two liquids. Biosurfactants act on the interface and are amphipathic molecules with both hydrophilic and hydrophobic moieties present within the same molecule. In literature the terms 'biosurfactants' and 'bioemulsifiers' are often used interchangeably owing to their unusual emulsifying property that makes them the molecules that enhance the accessibility and bioavailability of hydrophobic chemicals by forming stable emulsions and lowering the surface tension.

\footnotetext{
* Correspondence: kamalsekhon80@yahoo.com

'Department of Biotechnology and Environmental Sciences, Thapar

University, Patiala - 147001, Punjab, India

Full list of author information is available at the end of the article
}

Economy is often the drawback of all biotechnological processes, especially in the case of biosurfactant production. The economics of producing biosurfactants has limited its commercial applications [1], but the production cost can be reduced by improving yield, rate, recovery and using cheap or waste substrates.

Biosurfactants have carved a niche for themselves with their unusual antibacterial, antifungal and antiviral activities $[2,3]$. In biomedical sciences, some of the uses of biosurfactants include their role as anti-adhesive agents to pathogens, making them useful for treating many diseases and as therapeutic, probiotic and pharmaceutical agents $[1,2,4,5]$. In addition biosurfactants have a huge repertoire that enables them to degrade a wide range of organic pollutants [6]. The prospects of biosurfactants have a great potential because of their applications in the petroleum industry $[1,7,8]$ and microbial enhanced 
oil recovery [9-14]. The Rhodococcus ruber biosurfactants are found to be 1.4 to 2.3 times more efficient then the synthetic surfactants (Tween 20, Tween 60) in enhanced crude oil desorption and mobilization from soil core, with 65-82\% crude oil recovery [15].

There is increasing interest for isolating new enzymes and new enzyme producing strains for their use in industrial conversions [16]. Among these enzymes lipases, esterases, cellulases, xylanases and pectinases play an important role. Esterases have proven to be versatile enzymes as they catalyze reverse reactions, namely ester synthesis and transesterification (in non-aqueous systems), and they can catalyze stereoselective and regioselective reactions, making them good candidates for the production of optically active compounds used in the pharmaceutical and agricultural industries. Moreover, esterases and lipases show activity on a great variety of substrates, with no requirement for added cofactors [17]. Thus, they are very interesting biocatalysts for industrial purposes such as detergency, flavour production, paper recycling, chemical synthesis and resolution of racemic mixtures [18].

The present paper will focus on biosurfactant yield enhancement through cloning and the role played by esterases in the production of biosurfactants. The correlation between biosurfactant production and esterase activity in Bacillus species has not been explored in the literature so far. The aim of the study is to investigate the range of renewable and non-conventional substrates that can be used for enhanced biosurfactant production, making it a commercially viable process. The recombinant strains need to be exploited and the technology transfer to biotechnology industries can be extremely beneficial.

\section{Materials and methods}

\section{Bacterial strains, vectors and growth conditions}

Bacillus subtilis (designated as Bacillus subtilis SK320 throughout the paper) was isolated from endosulfan (organochlorine pesticide) sprayed cashew plantation soil in Ernakulum, Kerala (India). The isolate was identified as Bacillus subtilis by MTCC, Institute of Microbial Technology, Chandigarh, India. E. coli DH5 $\alpha$ was also obtained from MTCC. pGEM-T easy vector system was obtained from Promega Corporation, Madison, USA and was used according to the manufacturers instructions. Bacillus subtilis SK320 and the three recombinants were grown at $37^{\circ} \mathrm{C}, 120 \mathrm{rpm}$ in the basal media Bushnell Hass Broth (BHB) in a $100 \mathrm{ml}$ flask with $0.5 \%$ olive oil (v/v) (Olio di Oliva, Sasso, Milano, Italy) as a carbon source.

\section{Biosurfactant and/or Bioemulsifying Activity}

Bioemulsifying activity of the biosurfactant was measured with the culture supernatant obtained by centrifuging the bacterial growth at $12,000 \times g$ at $4^{\circ} \mathrm{C}$ for $30 \mathrm{~min}$. Later 5 $\mathrm{ml}$ of supernatant in a glass tube and $100 \mu \mathrm{l}$ of mobile oil was added and the contents were vortexed vigorously for $1 \mathrm{~min}$ at full speed and then left undisturbed for $10 \mathrm{~min}$ [19]. Bioemulsifying activity of the biosurfactant was measured at $550 \mathrm{~nm}$ spectrophotometrically (U-2001, Hitachi) in glass cuvette against blank of un-inoculated medium $(5 \mathrm{ml})$ with $100 \mu \mathrm{l}$ of mobile oil vortexed similar to the sample. Mobile oil or 2T Engine oil (Racer 2, Hindustan Petroleum Corporation Ltd, Govt. of India Enterprise, Mumbai) was obtained from a local petrol station. It is recommended as a pre-mix and oil injection system for 2 stroke engines.

\section{Surface tension measurement}

The reduction in surface tension (dynes/cm) was measured by the ring method (Du-Nouy principle) using a tensiometer (Petro-Diesel Instruments Company, Jencon, Calcutta, India). The purified biosurfactant from Bacillus subtilis SK320 and the recombinants were dissolved at a concentration of $1 \mathrm{mg} / 100 \mathrm{ml}$ i.e. CMC of $10 \mathrm{mg} / \mathrm{L}$ in distilled water and used for surface tension measurements against distilled water as a control.

\section{Esterase Activity}

Esterase was measured using $100 \mathrm{mM}$ para-nitrophenyl (pNp) acetate as substrate and $75 \mathrm{mM}$ phosphate buffer containing $10 \mathrm{mM} \mathrm{MgSO}_{4}(\mathrm{pH} \mathrm{7.0)}$. After $30 \mathrm{~min}$ of incubation at $37^{\circ} \mathrm{C}$ enzyme activity was monitored spectrophotometrically (U-2001, Hitachi) by measuring the increase in optical density at $405 \mathrm{~nm}$. Specific activity was expressed as $\mu$ moles/mg protein/min [20].

\section{Cloning of the biosurfactant genes}

Chromosomal DNA from Bacillus subtilis SK320 was isolated using the Rose method [21] and amplified using gene specific primers (Table 1). The primers were designed using the following website: http://frodo.wi.mit. edu/primer3. The primers were prepared by Operon Biotechnologies, Nattermannallee, Germany and supplied by Genetix Biotech Asia Private Ltd, New Delhi, India. The reaction mixture containing the chromosomal DNA,

Table 1 Gene specific primers used for amplification of chromosomal DNA of Bacillus subtilis SK320

\begin{tabular}{ccc}
\hline Gene & Primer Sequence 5'-3' & $\begin{array}{c}\text { Recombinants } \\
\text { (designation) }\end{array}$ \\
\hline sfp & 5'-CGTTCGCTCAGTCATAAGCA-3' & Bios $\boldsymbol{a}$ \\
& 5'-CCTGTATGCACACCCATCTG-3' & \\
sfpo & 5'-CTAGAATTCAGATTACGGAATTATATG-3' & Bios $\boldsymbol{b}$ \\
& 5'-GGGGAATTCAGGGTGTGCGGCGCATAC-3' & \\
srfa & 5'-TCCGTTTTCCTTGTCACC-3' & Bios c \\
& 5'-TCTTCTGCCACTGCATCAC-3' & \\
\hline
\end{tabular}


reverse primer, forward primer, dNTP mix, Taq DNA polymerase, Taq buffer and sterile water was amplified using GeneAmp PCR System 9700 (Applied Biosystems, Foster, CA, USA), with the program set to denaturation at $94^{\circ} \mathrm{C}$ for $5 \mathrm{~min}$, annealing at $45^{\circ} \mathrm{C}$ for $1 \mathrm{~min}$ and extension at $72^{\circ} \mathrm{C}$ for $1 \mathrm{~min}$ for a total of 30 cycles, with a final extension at $72^{\circ} \mathrm{C}$ for $10 \mathrm{~min}$. The PCR amplified product of the chromosomal DNA was ligated and cloned into the pGEM-T easy vector system. Transformation was carried out by $\mathrm{CaCl}_{2}$ method [22]. The transformants were selected on $\mathrm{Amp}^{+} \mathrm{X}$-gal IPTG plates. The nucleotide sequences of the genes viz. $s f p, s f p 0$ and $s r f A$ were determined by the dideoxy-chain termination method [23] using the Applied Biosystems DNA sequencer.

\section{Determination of the expression of biosurfactant genes}

For testing the expression of the biosurfactant genes, Bacillus subtilis SK320 and the positive transformants (recombinants) viz.BioS $a, \operatorname{BioS} b$ and $\operatorname{BioS} c$ were grown on a basal medium containing $0.5 \%(\mathrm{v} / \mathrm{v})$ olive oil at $37^{\circ} \mathrm{C}$, respectively. Ampicillin was supplemented in the medium used for growing the positive transformants. Growth, biosurfactant and esterase activities were estimated at an interval of $24 \mathrm{~h}$ for 5 days, respectively.

\section{Recovery and purification of the biosurfactant}

Bacillus subtilis SK320 and the recombinants were grown in BHB containing $0.5 \%$ olive oil (v/v) as the carbon source. After $48 \mathrm{~h}$, when the biosurfactant activity was observed to be maximum in the supernatant, the culture was harvested at $7000 \times g$ for $30 \mathrm{~min}$ at $4{ }^{\circ} \mathrm{C}$. Supernatant was filtered through Whatman No. 42 filter paper and 3 volumes of chilled acetone was added to the supernatant and left at $-20^{\circ} \mathrm{C}$. After $18-24 \mathrm{~h}$ the solution was centrifuged at $7000 \times g$ for $30 \mathrm{~min}$ at $4^{\circ} \mathrm{C}$, air dried and then dissolved in water. This step was repeated 2-3 times for purification. The final precipitate was dissolved in water and the sample was lyophilized (Heto LyoLab 3000 Lyophilizer, Germany). The lyophilized sample was then estimated for biosurfactant activity at $550 \mathrm{~nm}$. For estimating total biosurfactant recovery the purified (lyophilized) powder was weighed and reported as $\mathrm{g} / \mathrm{L}$.

\section{Characterization of the biosurfactant \\ Lipid}

The dried partially purified sample was extracted with chloroform: methanol solution $(2: 1, \mathrm{v} / \mathrm{v})$. The suspension was allowed to stand at room temperature for 5-10 min and then centrifuged and supernatant collected. An aliquot ( 0.2 volume) of distilled water was added to the sample so as to remove any traces of chloroform:methanol, if present. The sample was then vortexed. After giving 2-3 washings with MQ water, the lower layer containing the lipid was transferred to a fresh tube and the sample was lyophilized and weighed to get the total lipid content.

Ash

A known weight of lyophilized sample was taken in a pre-weighed glass crucible and kept in the oven for $1 \mathrm{~h}$ at $80^{\circ} \mathrm{C}$. After evaporating the excessive moisture the charred sample was transferred to the silica crucible and weighed. The sample was then kept in an electric muffle furnace at $550 \pm 50^{\circ} \mathrm{C}$ for $5 \mathrm{~h}$. The cooled crucible was then weighed for residual ash.

\section{Protein}

Extracellular protein in the supernatant and protein content in the purified biosurfactant was measured at $310 \mathrm{~nm}$ using the biuret method [24] using bovine serum albumin as standard. The total volume of protein sample was made up to $2 \mathrm{ml}$ with Milli-Q water and 1 $\mathrm{ml}$ of biuret reagent. After $10 \mathrm{~min}$ incubation at room temperature, the absorbance was measured at $310 \mathrm{~nm}$ against a reagent blank in a spectrophotometer (U-2001, Hitachi).

\section{Carbohydrate}

The carbohydrate content was measured at $620 \mathrm{~nm}$ using the anthrone method [25] using glucose as standard. The total volume was made to $2 \mathrm{ml}$ with sample, distilled water and $2 \mathrm{ml}$ of anthrone reagent $(0.2 \mathrm{~g}$ anthrone in $100 \mathrm{ml}$ conc. $\mathrm{H}_{2} \mathrm{SO}_{4}$ ). The test tubes were covered and kept in a boiling water bath. After $10 \mathrm{~min}$, the test tubes were cooled down by incubation on ice for $5 \mathrm{~min}$ to stop the reaction. Absorbance was read at $620 \mathrm{~nm}$ against a reagent blank.

\section{Effect of Proteinase K and Lipase (Steapsin) on purified biosurfactant}

Proteinase $\mathrm{K}$ and Lipase were procured from MBI Fermentas and Himedia, respectively.

\section{Proteinase $K$}

The purified biosurfactant $(1 \mathrm{mg} / \mathrm{ml})$ was incubated with different concentrations of Proteinase K (viz. 0.5, 1, 2, 4 $\mathrm{mg}$ ) at $37^{\circ} \mathrm{C}$. Samples were withdrawn at different time intervals (i.e. 10, 30, 60, 120 mins) and assayed for biosurfactant activity at $550 \mathrm{~nm}$.

\section{Lipase (Steapsin)}

The purified biosurfactant was incubated with 100, 200, 500,700 and $1000 \mu \mathrm{g}$ of lipase and incubated at $37^{\circ} \mathrm{C}$. Samples were withdrawn at regular intervals (i.e. 30, 60, 90, 120 mins) and assayed for biosurfactant activity at $550 \mathrm{~nm}$.

\section{Results and Discussion}

\section{Regulation of Biosurfactant production with various} substrates

Bacillus subtilis SK320 was grown on basal medium containing various substrates $(0.5 \%, \mathrm{v} / \mathrm{v})$ and monitored 
for growth and biosurfactant activity. The various carbon sources used were vegetable oil, glycerol, maltose, n-dodecane, mobile oil, crude oil, olive oil, glucose and sucrose. Bacillus subtilis SK320 was also grown on tween 40, tween 60 and triton X-100, but as these three substrates are also effective synthetic surfactants, formation of emulsion (foam) in the medium at $37^{\circ} \mathrm{C}$ was observed with increasing incubation time, this made it difficult to analyse the growth. Among the various carbon sources tested for biosurfactant production by Bacillus subtilis SK320 in basal medium olive oil, glucose, glycerol and sucrose, produced maximum activity in the range of 0.859 to 0.121 (optical density). Low levels of biosurfactant activity in the range of 0.074 to 0.014 (optical density) were detected when grown in the presence of maltose, vegetable oil, mobile oil, ndodecane, crude oil (Table 2). During the years wide range of carbon sources such as peat hydrolysate for $B$. subtilis [26], soy bean curd residue (okara) for B. subtilis YB8 and B. subtilis MI113 [27], n-hexadecane, paraffinic oil, babassu oil for P. aeruginosa PA1 [28], and soybean oil, safflower oil, glycerol for P. aeruginosa GS9-119 and DS10-129 [29], glycerol [30], molasses medium supplemented with soya-okra for $P$. aeruginosa MTCC 2297 [31] have been reported to induce biosurfactant production. Cheap substrates such as vegetable oils and oil wastes, plant-derived oils, lactic whey and distillery wastes, starchy substrates, olive oil mill effluent, animal fat, soapstock and molasses have the potential for enhancing biosurfactant production [32]. The oils mostly used for biosurfactant production are edible oils and are not cheap [33]. The novelty and viability of the biosurfactant production process depends equally on the yield and the rate of production. Therefore, the oils used for biosurfactant production should not be very expensive but should be economical enough to give the industry a cost-effective technology.
The biosurfactant activity in the supernatant, containing olive oil as substrate, increased with time. Maximum activity was achieved during the stationary phase between 48 to $72 \mathrm{~h}$ of growth when the nutrient limiting conditions started prevailing in the growth medium. The production of surfactin in culture broth of Bacillus subtilis [34], rhamnolipids by Pseudomonas aeruginosa [35], emulsan in Acinetobacter calcoaceticus RAG-1 [36], exopolysaccharide in A. calcoaceticus BD4 [37] and rhamnolipid AP-6 in P. fluorescens 378 [38] were all found to be growth associated. The rate of growth of all these bacteria varied but maximum biosurfactant activity was only observed when the bacterium entered the stationary phase irrespective of its growth rate. It was postulated that in bacteria, growth and product formation (biosurfactant) proceed as separate events [39]. Bacillus subtilis SK320 grew luxuriantly in the basal medium and was also capable of emulsifying olive oil to a greater extent. The low level of biosurfactant activity at $120 \mathrm{~h}$ coincided with the complete emulsification of olive oil in the basal medium, visualized as a milky appearing growth medium. Similar results showed that the bioemulsifier emulsan produced by oil-degrading microorganism Acinetobacter venetianus RAG-1 [36] and the biosurfactant produced by Pseudomonas aeruginosa [40] was responsible for forming stable oil-water emulsions with hydrophobic substrates such as hexadecane. The extracellular protein analyzed was maximum $(6.97 \mathrm{mg} /$ $\mathrm{ml}$ ) when olive oil was used as the substrate followed by vegetable oil, glycerol and glucose. The protein content was found to be minimum with mobile oil and crude oil with values as low as 0.18 and $0.23 \mathrm{mg} / \mathrm{ml}$.

\section{Induction of esterase activity}

Esterase activity was found to be correlated to biosurfactant production in Bacillus subtilis SK320. Olive oil was the best inducer of esterase activity amongst all the substrates with the highest activity of $4.382 \mathrm{IU} / \mathrm{ml}$, followed

Table 2 Biosurfactant activity, esterase activity, extracellular protein and biosurfactant yield of Bacillus subtilis SK320 on various substrates after $72 \mathrm{~h}$

\begin{tabular}{ccccc}
\hline Substrate & $\begin{array}{c}\text { Biosurfactant activity } \\
\text { (OD } \text { at } \mathbf{5 5} \mathbf{~ n m})\end{array}$ & $\begin{array}{c}\text { Esterase activity } \\
(\mathbf{I U} / \mathbf{m l})\end{array}$ & $\begin{array}{c}\text { Extracellular Protein } \\
\text { (micrograms/ml) }\end{array}$ & $\begin{array}{c}\text { Biosurfactant Recovery } \\
(\mathbf{g} / \mathbf{L})\end{array}$ \\
\hline Vegetable oil & 0.048 & 0.4248 & 2.66 & 0.15 \\
Glycerol & 0.137 & 0.6616 & 2.37 & 0.21 \\
Maltose & 0.074 & 0.7929 & 1.23 & 0.18 \\
n-dodecane & 0.019 & 0.1338 & 0.32 & 0.08 \\
Mobile oil & 0.035 & 0.1853 & 0.18 & 0.09 \\
Crude oil & 0.014 & 0.1081 & 0.23 & 0.06 \\
Olive oil & 0.859 & 4.382 & 6.97 & 1.2 \\
Glucose & 0.185 & 0.3552 & 2.37 & 0.27 \\
Sucrose & 0.121 & 0.5097 & 2.29 & 0.19 \\
\hline
\end{tabular}

† Results represented as mean of at least three replicate experiments. 
by maltose, glycerol, sucrose and vegetable oil with activities of $0.7929,0.6616,0.5097$ and $0.4248 \mathrm{IU} / \mathrm{ml}$, respectively (Table 2 ). This is in contrast to the observation in Pseudomonas fluorescens DSM 50106, Rhodosporidium toruloides, Pseudomonas putida NRRL B18435 and Acinetobacter calcoaceticus RAG-1 where maximum esterase activity was observed in a nutrient rich medium with glucose as the carbon source [20,41-43]. But it was shown that production of type I and II esterases by Bacillus licheniformis S-86 was substantially enhanced by 1.6 and 2.2 times, when oils and surfactants were supplied as carbon sources [44]. The majority of the esterase produced in Bacillus subtilis SK320 was extracellular as the cells, after sonication, gave very low esterase activity. In Acenitobacter sp. [45], most of the esterase activity was found to be cell associated and only slight amounts appeared in the external medium during late growth whereas in A. calcoaceticus RAG-1 [46] esterase activity was found both in cell free broth and on the cell surface. With a decrease in the cell-bound activity there was an increase in the cell free esterase activity during growth. In Bacillus subtilis SK320 the production of esterase increased progressively during growth following the same trend as that of the biosurfactant production and was maximum at $72 \mathrm{~h}$. After $72 \mathrm{~h}$ there was a reduction in the esterase activity after which it remained constant until $192 \mathrm{~h}$. In $A$ calcoaceticus BD 413 [47] a large amount of esterase and biosurfactant activity was produced during the transition from the exponential to the stationary phase, while in $A$ calcoaceticus RAG-1 [36] esterase activity followed the growth pattern, with the maximum activity being achieved during the stationary phase of growth. In Acinetobacter venetianus RAG-1 the release of emulsan from the bacterial cell surface was mediated by the action of a cell surface esterase, which is one of the key components in the active emulsan-protein complex and itself appears in the growth medium just prior to the appearance of the cell-free emulsifying activity [47].

\section{Cloning and expression of biosurfactant genes}

Bacillus subtilis SK320 and recombinant strains $\operatorname{BioS} a$, $\operatorname{BioS} b$ and $\operatorname{BioS} c$, cultivated on a basal medium containing $0.5 \%(\mathrm{v} / \mathrm{v})$ olive oil at $37^{\circ} \mathrm{C}$ were compared for their growth, biosurfactant and esterase activities. Growth was observed to be maximum in Bacillus subtilis SK320 followed by BioS a, BioS $b$ and BioS $c$, whereas biosurfactant and esterase activities were found to be enhanced in the recombinants in comparison to the parent strain (Table 3). There was negligible growth in the case of E.coli DH5 $\alpha$ strain when it was grown on a basal medium containing olive oil indicating that E.coli DH5 $\alpha$ was unable to utilize olive oil as the carbon source. The screening of biosurfactant and esterase
Table 3 Growth, biosurfactant and esterase activity of Bacillus subtilis SK320 and recombinants at $72 \mathrm{~h}$ of growth

\begin{tabular}{|c|c|c|c|}
\hline Source & $\begin{array}{l}\text { Biosurfactant activity } \\
\text { (OD } 550 \mathrm{~nm})\end{array}$ & 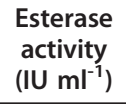 & $\begin{array}{c}\text { Growth } \\
\text { (OD } 600 \mathrm{~nm} \text { ) }\end{array}$ \\
\hline $\begin{array}{l}\text { Bacillus subtilis } \\
\text { SK320 }\end{array}$ & 0.859 & 4.382 & 0.514 \\
\hline Bios a & 1.354 & 8.293 & 0.351 \\
\hline BiOS $b$ & 1.259 & 8.521 & 0.296 \\
\hline BioS C & 1.198 & 8.465 & 0.489 \\
\hline E. coli $\mathrm{DH} 5 \alpha$ & 0.157 & 0.101 & 0.132 \\
\hline
\end{tabular}

† Results represented as mean of at least three replicate experiments.

positive strains was also confirmed from the fact that $E$. coli strains DH5 $\alpha$, HB101 and MM294 could not grow on simple triglycerides [43]. There was no apparent biosurfactant and esterase activity found in the parent $E$. coli $\mathrm{DH} 5 \alpha$, whereas the recombinant strains which possess an active biosurfactant gene were now able to utilize olive oil as a carbon source. Data revealed that the biosurfactant genes were not only successfully cloned and expressed but they were over-expressed in $\operatorname{BioS} a$, $\operatorname{BioS} b$ and $\operatorname{BioS} c$ showing a twofold increase in the activity then the parent strain (Table 3). The biosurfactant activity increased in the first $24 \mathrm{~h}$ producing the maximum activity between 48 to $72 \mathrm{~h}$. After $72 \mathrm{~h}$ biosurfactant activity started showing a decline reaching a minima at $120 \mathrm{~h}$. Maximum biosurfactant activity was observed in case of the recombinant $\operatorname{BioS} b$ followed by BioS $a$ and Bio $c$. Olive oil supplemented in the culture media was found to be completely emulsified after 120 h. Cloning of the biosurfactant genes from Bacillus subtilis SK320 into E.coli not only resulted in the expression of the biosurfactant activity but also conferred esterase production in the recombinant cells. Similarly, cloning, sequencing and characterization of a genomic region of $B$. subtilis B3 comprising srfDB3, aspB3, lpab3 and $y c z E B 3$ genes was carried out and it was observed that the $\operatorname{srfDB} 3$ gene encodes thioesterase which is required for biosynthesis of surfactin in B. subtilis [48]. Esterase activity of $\operatorname{BioS} a, \operatorname{BioS} b$ and $B i o S c$ was found to be enhanced when compared to Bacillus subtilis SK320.

\section{Phylogenetic analysis of three biosurfactant genes}

The genes $s f p$ (1210 bp), sfpO (642 bp) and $s r f A$ (707 bp) were successfully cloned and sequenced using an Applied Biosystems DNA Sequencer (DDBJ/EMBL/GeneBank accession numbers are: EU822921, EU822922 \& EU822923). The DNA sequences were used to infer functional and evolutionary relationships between sequences in the database and to identify members of gene families using the NCBI BLAST (http://www.ncbi. 
nlm.nih.gov/BLAST) facility. The results revealed sequence homology of the $s f p$, $s f p 0$ and $s r f A$ genes with Bacillus subtilis surfactin synthetase gene, Bacillus amyloliquefaciens, Bacillus licheniformis, Bacillus megaterium, Bacillus subtilis srfAA, several lipases from yeast and filamentous fungi to name a few. In addition much weaker similarities were also observed. Based on the matching sequences found with BLAST, it was estimated that the greatest overall similarity (99.0\%) was with the biosurfactant and esterase genes of Bacillus subtilis. Multiple alignments of the deduced amino acid sequences from $s f p$, $s f p 0$ and $s r f A$ were carried out with two esterase gene sequences viz. Bacillus sp. NK13 esterase gene (Accession number: DQ196347) [Liu G, Tan Z, Zhang J. Cloning of esterase gene from Bacillus sp. NK13. Submitted] and Bacillus clausii KSM-K16 esterase gene (Accession number: AP006627) [49]. The results indicated similarity and conserved family characteristics between the biosurfactant and esterases genes, confirming our prediction of a possible correlation between the two activities (Figure 1).

\section{Purification and characterization of Biosurfactant}

Bacillus subtilis SK320 and the recombinants BioS a, $\operatorname{BioS} b$ and $\operatorname{BioS} c$, were grown in a basal medium with $0.5 \%(\mathrm{v} / \mathrm{v})$ olive oil and the purified biosurfactant was lyophilized to obtain a clear powder. The biosurfactant yield (\%) obtained from $\operatorname{BioS} a, \operatorname{BioS} b$ and $\operatorname{BioS} c$ was much higher than that obtained for parent Bacillus subtilis SK320 i.e. $1.2 \mathrm{~g} / \mathrm{L}$ (Table 4). Surface tension values were found to be 72.1 dynes/cm for tap water and 70.7 dynes/cm for sterile Milli-Q water. Biosurfactant extracted from the parent Bacillus subtilis SK320 was able to reduce the surface tension of tap water to 40.1 dynes $/ \mathrm{cm}$, whereas the biosurfactant obtained from recombinants $\operatorname{BioS} a, \operatorname{BioS} b$ and $B i o S c$ reduced the surface tension of tap water to as low as 38.4, 35 and 30.7 dynes $/ \mathrm{cm}$, respectively (Table 4 ). Results suggested that the successful expression of the biosurfactant gene was responsible for the surface tension reduction by the biosurfactants. Total production yield of the lipopeptides from Bacillus subtilis BBK-1 was about $480 \mathrm{mg} / \mathrm{L}$ at $30^{\circ}$ $\mathrm{C}$ for $24 \mathrm{~h}$ [50], whereas Bacillus sp. strain IAF 343 gave the yield of $1 \mathrm{~g} / \mathrm{L}$ on medium containing only water soluble substrates [19]. P. aeruginosa DS10-129 produced 4.31, 2.98 and $1.77 \mathrm{~g} / \mathrm{L}$ rhamnolipid biosurfactant using soybean oil, safflower oil and glycerol as substrates [51]. Bacillus cereus IAF 346 produced a monoglyceride biosurfactant that lowered the surface tension of water to $28 \mathrm{mN} / \mathrm{m}$ with a yield of $1.6 \mathrm{~g} / \mathrm{L}(\mathrm{pH} 6.5)$ and $1.7 \mathrm{~g} / \mathrm{L}$ (pH 7.0) [19]. B. subtilis grown on medium containing $4 \%$ glucose gave the yield of $1-2 \mathrm{~g} / \mathrm{L}$ of biosurfactant with minimum surface tension of $27 \mathrm{mN} / \mathrm{m}$ [52]. $B$. licheniformis JF-2 anaerobically produced biosurfactant when grown in glucose rich medium and reduced surface tension of water to $28 \mathrm{mN} / \mathrm{m}$ [53]. Purified lichenysin A from B. licheniformis BAS50 decreased the surface tension of water to $28 \mathrm{mN} / \mathrm{m}$ with a yield of $70-160$ $\mathrm{mg} / \mathrm{L}$ [54]. The maximum yield of surfactin was approximately $110 \mathrm{mg} / \mathrm{lit}$ by the strain B. subtilis S 499 [55]. In a very recent study, biosurfactant production of $1.74 \mathrm{~g} / \mathrm{L}$ was observed when the microbial consortium of Enterobacter cloacae and Pseudomonas sp. (ERCPPI2) was grown on minimal salt medium supplemented with olive oil $(1 \%, \mathrm{w} / \mathrm{v})$ and $1 \%(\mathrm{w} / \mathrm{v})$ sodium nitrate supplemented with $1.39 \%(\mathrm{w} / \mathrm{v}) \mathrm{K}_{2} \mathrm{HPO}_{4}$ at $40^{\circ} \mathrm{C}$ and $150 \mathrm{rpm}$ after $48 \mathrm{~h}$ incubation. The consortium ERCPPI-2 was able to reduce the surface and interfacial tensions to 31.7 and $0.65 \mathrm{mN} / \mathrm{m}$ [14].

Various biochemical and physiological properties of the biosurfactants were studied after its purification. The biochemical analysis revealed that the purified biosurfactant from BioS a had $89.70 \%$ lipid, 14.9\% ash, $7.21 \%$ protein and $3.08 \%$ carbohydrate content. Biosurfactant from BioS b contained 90.30\% lipid, 15.20\% ash, $6.73 \%$ protein and $2.94 \%$ carbohydrate content whereas, biosurfactant obtained from BioS c contained 91.0\% lipid, $15.38 \%$ ash, $6.26 \%$ protein and $2.70 \%$ carbohydrate content, respectively. The biosurfactant from all the three recombinant strains had a high lipid content thereby affirming that the biosurfactants belong to the class of lipopeptides. These results were in accordance with Bacillus subtilis SK320 biosurfactant, which had $7.45 \%$ protein, $89.40 \%$ lipid, $3.15 \%$ carbohydrate and $14.5 \%$ ash content, respectively.

Boiling or incubating the biosurfactant with proteinase $\mathrm{K}$ led to a decrease in biosurfactant and emulsifying activity, indicating that the protein (esterase) moiety was essential for biosurfactant activity (Figure 2). The decrease in activity of the purified biosurfactant at $\mathrm{pH}$ 8.0 and above also indicated an active role of the protein moiety, as the loss in activity at high $\mathrm{pH}$ may be due to the denaturation of the protein. Lipids constituted a large percentage of the purified biosurfactant and therefore regulated the biosurfactant activity in a significant manner. The incubation of biosurfactant with lipase resulted in appreciable loss in biosurfactant activity (up to $100 \%$ ) (Figure 3). In Pseudomonas PGI [56], the protein moiety was shown to be essential for biosurfactant activity as incubation of the biosurfactant with chymotrypsin reduced both solubilizing and emulsifying activities to very low levels. Similarly, in A. calcoaceticus $\mathrm{BD} 4$, the polysaccharide moiety of the biosurfactant alone showed no emulsification activity, however polysaccharide released with protein during growth showed potent emulsification activity [57]. In A. calcoaceticus RAG-1, the protein moiety of the emulsan was not at all involved in the activity as the deproteinized emulsan 


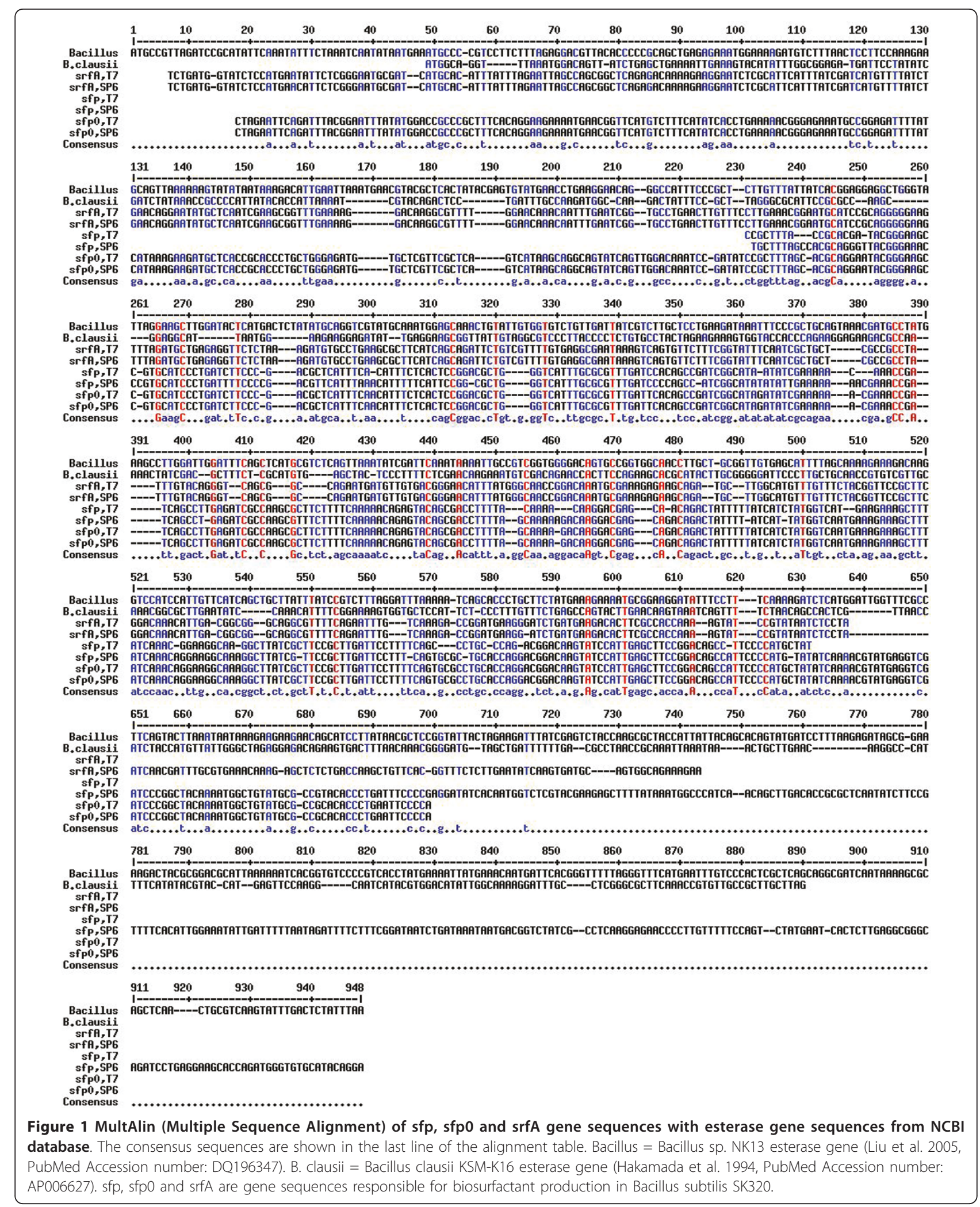


Table 4 Surface tension values and yield of purified biosurfactant from Bacillus subtilis SK320 and its recombinants

\begin{tabular}{lcc}
\hline & $\begin{array}{c}\text { Biosurfactant recovery } \\
\text { (g/L) }\end{array}$ & $\begin{array}{c}\text { Surface tension } \\
\text { (dynes/cm) }\end{array}$ \\
\hline Bacillus subtilis & 1.2 & 40.1 \\
SK320 & & \\
BioS a & 2.13 & 38.4 \\
BioS b & 2.20 & 35 \\
BioS C & 2.45 & 30.7 \\
\hline
\end{tabular}

† Results represented as mean of at least three replicate experiments.

retained all its biosurfactant activity. Emulsan was later characterised to be a lipopolysaccharide [46]. The biosurfactant of Bacillus subtilis SK320 contained 7.45\% protein $(\mathrm{w} / \mathrm{w})$, which was almost one third when compared to $34 \%(\mathrm{w} / \mathrm{w})$ in Pseudomonas PG-1 [56]. The amount of lipid was more when compared with the lipid content $(32 \%, \mathrm{w} / \mathrm{w})$ in Pseudomonas PG-1. The difference in the chemical composition could be due to the different growth conditions. Bacillus subtilis SK320 was grown on basal medium with olive oil as the carbon source, while Pseudomonas PG-1 was grown in minimal medium with hexadecane/pristane as the substrate $[46,58]$.

\section{Conclusions}

Bacillus subtilis SK320 produces a biosurfactant that belongs to the class of lipopeptides having excellent emulsifying properties. It has been shown that biosurfactant production is mediated by extracellular esterase in the growth medium of Bacillus subtilis SK320 and its recombinant strains. Biosurfactants devoid of protein or lipid components showed much lower emulsifying

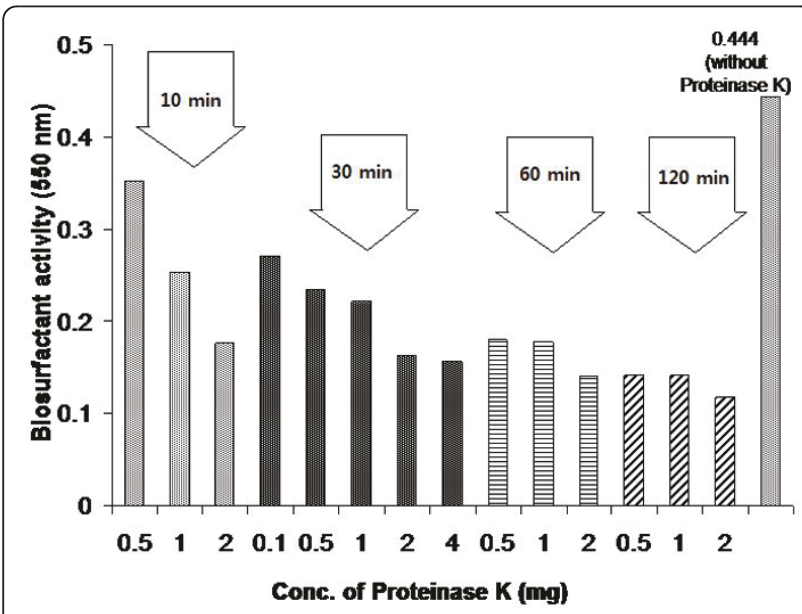

Figure 2 Effect of Proteinase K on purified biosurfactant. The purified biosurfactant was incubated at $37^{\circ} \mathrm{C}$ with various proteinase $\mathrm{K}$ concentrations for $10,30,60$ and $120 \mathrm{~min}$. The sample was analyzed for biosurfactant activity at $550 \mathrm{~nm}$.

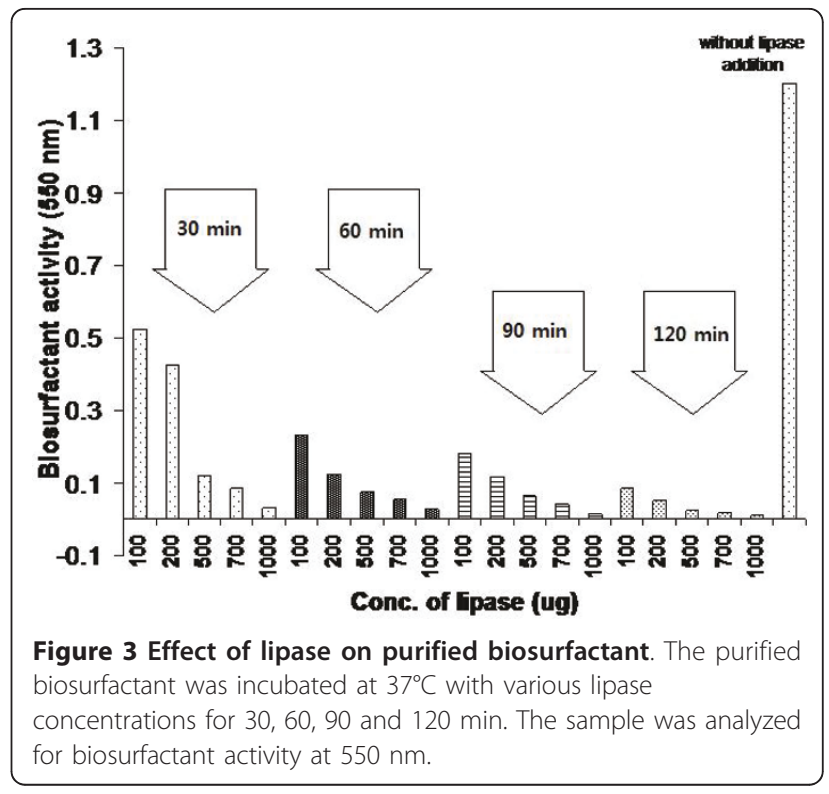

activity. The recombinant strains showed a twofold increase in the esterase activity and biosurfactant yield. The biosurfactants were capable of reducing the surface tension of water to a significantly lower value. These properties are of great importance in bioremediation and various other industrial applications.

\section{Acknowledgements}

KKS is thankful to the Centre of Relevance and Excellence and the Department of Biotechnology and Environmental Sciences, Thapar University, Patiala where this research work was conducted. KKS is thankful to her brother Daljeet Singh Sekhon, for helping her in getting the manuscript checked for English by a professional proof-reader from London, UK.

\section{Author details}

'Department of Biotechnology and Environmental Sciences, Thapar University, Patiala - 147001, Punjab, India. ${ }^{2}$ NIIT University, Neemrana, Rajasthan - 301705, India. Institute of Microbial technology, Sector 39-A, Chandigarh - 160036, India.

\section{Authors' contributions}

KSS has carried out the research. SK has supervised the study and SSC assisted with his stimulating discussions and revision of the manuscript. All authors have read and approved the final manuscript.

\section{Competing interests}

The authors declare that they have no competing interests.

Received: 11 March 2011 Accepted: 27 June 2011

Published: 27 June 2011

\section{References}

1. Mulligan CN: Environmental applications for biosurfactants. Environ Pollution 2005, 133:183-198.

2. Cameotra SS, Makkar RS: Recent applications of biosurfactants as biological and immunological molecules. Curr Opin Microbiol 2004 7:262-266

3. Joshi S, Bharucha C, Desai AJ: Production of biosurfactant and antifungal compound by fermented food isolate Bacillus subtilis 20B. Biores Technol 2008, 99:4603-4608. 
4. Rodrigues J, Mei HCV, Teixeira J, Oliveira R: Influence of biosurfactants from probiotic bacteria on formation of biofilms on voice prostheses. Appl Environ Microbiol 2004, 70:4408-4410.

5. Eshrat G-F: Biosurfactants in pharmaceutical industry: A mini-review. Am J Drug Discov Dev 2011, 1:58-69.

6. Magdalena P-P, Grazyna AP, Zofia P-S, Cameotra SS: Environmental applications of biosurfactants: Recent advances. Int J Mol Sci 2011 12:633-654.

7. Banat IM: Biosurfactants production and possible uses in microbial enhanced oil recovery and oil pollution remediation: a review. Biores Technol 1995, 51:1-12.

8. Amedea P, Ivo R, Banat IM: Possibilities and challenges for biosurfactants use in petroleum industry. Adv Exp Med Biol 2010, 672:135-145.

9. Okpokwasili GC, Ibiene AA: Enhancement of recovery of residual oil using a biosurfactant slug. African J Biotech 2006, 5:453-456.

10. Youssef N, Simpson DR, Duncan KE, Mclnerney MJ, Folsbee M, Fincher T, Knapp RM: In situ biosurfactant production by Bacillus strains injected into a limestone petroleum reservoir. Appl Environ Microbiol 2007, 73:1239-1247.

11. Salehizadeh $\mathrm{H}$, Mohammadizad S: Microbial enhanced oil recovery using biosurfactant produced by Alcaligenes faecalis. Iranian J Biotechnol 2009, 7:216-223.

12. Amani H, Sarrafzadeh MH, Haghighi M, Mehrnia MR: Comparative study of biosurfactant producing bacteria in MEOR applications. J Pet Sci Eng 2010, 75:209-214.

13. Shavandi M, Mohebali G, Haddadi A, Shakarami H, Nuhi A: Emulsification potential of a newly isolated biosurfactant producing bacterium, Rhodococcus sp. strain TA6. Colloids and Surfaces B: Biointerfaces 2011, 82:477-482.

14. Darvishi P, Ayatollahi S, Mowla D, Niazi A: Biosurfactant production under extreme environmental conditions by an fficient consortium, ERCPPI-2. Colloids and Surfaces B: Biointerfaces 2011.

15. Kuyukina MS, Ivshina IB, Makarov SO, Litvinenko LV, Cunningham CJ, Philp JC: Effect of biosurfactants on crude oil desorption and mobilization in a soil system. Environ Int 2005, 31:155-161.

16. Cherry JR, Fidantsef AL: Directed evolution of industrial enzymes: an update. Curr Opin Biotechnol 2003, 14:438-43.

17. Schmidt-Dannert C: Recombinant microbial lipases for biotechnological applications. Bioorg Med Chem 1999, 7:2123-2130.

18. Jaeger KE, Dijkstra BW, Reetz MT: Bacterial biocatalysts: molecular biology, three-dimensional structures, and biotechnological applications of lipases. Annual Rev Microbiol 1999, 53:315-351.

19. Cooper DG, Goldenberg BG: Surface-active agents from two Bacillus species. Appl Environ Microbiol 1987, 53:224-229.

20. Politino M, Tonzi SM, Burnett W. Romancik G, Usher JJ: Purification and characterization of a cephalosporin esterase from Rhodosporidium toruloides. Appl Environ Microbiol 1997, 63:4807-4811.

21. Rose OC, Brookes MI, Mallet JLB: A quick and simple non-lethal method for extracting DNA from butterfly wings. Mol Eco 1994, 3:275.

22. Avery OT, Macleod CM, McCarty M: Studies on the chemical nature of the substance inducing transformation of pneumococcal types. $J$ Exp Med 1944, 149:297-326

23. Sanger F, Nicklen S, Coulson AR: DNA sequencing with chain-terminating inhibitors. Proc Natl Acad Sci USA 1977, 74:5463-5467.

24. Itzhaki RF, Gill DM: A micro Biuret method for estimating proteins. Anal Biochem 1964, 9:401-410.

25. Plummer DT: An introduction to Practical Biochemistry. Tata McGraw-Hil Publishing Company Ltd; Third 1988.

26. Mulligan CN, Sheppard JD: The production of surfactin by Bacillus subtilis grown on peat hydrolysate. App Microbiol Biotechnol 1987, 27:110-116.

27. Nakayama S, Takahashi S, Hirai M, Shoda M: Isolation of new variants of surfactin by a recombinant Bacillus subtilis. App Microbiol Biotechnol 1997, 48:80-82.

28. Anna LMS, Sebastain GV, Menezes EP, Alves TLM, Santos AS, Pereira N Freire DMG: Production of biosurfactants from Pseudomonas aeruginosa PA1 isolated in oil environments. Brazilian J Chem Engg 2002, 19:159-166.

29. Rahman KSM, Rahman TJ, McClean S, Marchant R, Banat IM: Rhamnolipid biosurfactant production by strains of Pseudomonas aeruginosa using low-cost raw materials. Biotechnol Prog 2002, 18:1277-1281.

30. Gervasio PDS, Matthias M, Jonas C: Glycerol: A promising and abundant carbon source for industrial microbiology. Biotech Adv 2009, 27:30-39.
31. Panesar R, Panesar PS, Bera MB: Development of low cost medium for the production of biosurfactants. Asian J Biotech 1996-0700 2011.

32. Muthusamy K, Gopalakrishnan S, Ravi TK, Sivachidambaram P: Biosurfactants: Properties, commercial production and application. Curr Sci 2008, 94:736-747.

33. Mukherjee S, Das P, Sen R: Towards commercial production of microbial surfactants. Trend Biotech 2006, 24:509-515.

34. Peypoux F, Bonmatin JM, Wallach J: Recent trends in the biochemistry of surfactin. App Microbiol Biotechnol 1999, 51:553-563.

35. Hisatsuka K, Nakahara T, Sano N, Yamada K: Formation of rhamnolipid by P.aeruginosa and its function in hydrocarbon fermentation. Agric Biol Chem 1971, 35:686-692.

36. Gutnick D, Bach H, Berdichevsky Y: An exocellular protein from the oildegrading microbe Acinetobacter venetianus RAG-1 enhances the emulsifying activity of the polymeric bioemulsifier emulsan. Appl Environ Microbiol 2003, 69:2608-2615.

37. Kaplan N, Rosenberg E: Exopolysaccharide distribution and bioemulsifier production in Acinetobacter calcoaceticus BD-4 and BD413. Appl Environ Microbiol 1982, 44:1335-1341.

38. Persson A, Osterberg E, Dostalek M: Biosurfactant production by Pseudomonas fluorescens 378: growth and product characteristics. Appl Microbiol Biotechnol 1988, 29:1-4.

39. Hommel RK, Ratledge C: Biosynthetic Mechanisms of low Molecular weight surfactants and their precursor molecules. In Biosurfactant Surfactant Science Series. Volume 48. Edited by: Kosaric, N. Marcel Dekker, Inc., New York; 1993:64

40. Cameotra SS, Singh P: Synthesis of rhamnolipid biosurfactant and mode of hexadecane uptake by Pseudomonas species. Micro Cell Fac 2009, 8:16-22.

41. Khalameyzer V, Fischer I, Bornscheuer UT, Altenbuchner J: Screening, nucleotide sequence, and biochemical characterization of an esterase from Pseudomonas fluorescens with high activity towards lactones. Appl Environ Microbiol 1999, 65:477-482.

42. Hasona A, York SW, Yomano LP, Ingram LO, Shanmugam KT: Decreasing the level of ethyl acetate in ethanolic fermentation broths of Escherichia coli KO11 by expression of Pseudomonas putida estZ esterase. Appl Environ Microbiol 2002, 68:2651-2659.

43. Reddy PG, Allon R, Mevarech M, Mendelovitz S, Sato Y, Gutnick DL: Cloning and expression in Escherichia coli of an esterase coding gene from the oil-degrading bacterium Acinetobacter calcoaceticus RAG-1. Gene 1989, 76:145-152.

44. Torres S, Baigori MD, Pandey A, Castro GR: Production and Purification of a solvent-resistant esterase from Bacillus licheniformis S-86. Appl Biochem Biotechnol 2008, 151:221-232.

45. Breuil C, Kushner DJ: Lipase and esterase formation by psycrophilic and mesophilic Acinetbacter species. Can J Micribiol 1975, 21:423-33.

46. Shabtai Y, Gutnick DL: Exocellular esterase and emulsan release from the cell surface of Acinetobacter calcoaceticus. J Bacteriol 1985, 161:1176-1181.

47. Kok RG, Christoffels VM, Vosman B, Hellingwerf KJ: Growth-phasedependent expression of the lipolytic system of Acinetobacter calcoaceticus BD413: cloning of a gene encoding one of the esterases. J Gen Microbiol 1993, 139:2329-2342.

48. Yao S, Gao X, Fuchsbauer HW, Vater J, Wang J: Cloning, sequencing, and characterization of the genetic region relevant to biosynthesis of the lipopeptides Iturin A and surfactin in Bacillus subtilis. Curr Microbiol 2003, 47:272-277.

49. Hakamada Y, Kobayashi T, Hitomi J, Kawai S, Ito S: Molecular cloning and nucleotide sequence of the gene for an alkaline protease from the alkalophilic Bacillus sp. KSM-K16. J Ferment Bioeng 1994, 78:105-108.

50. Roongsawang N, Thaniyavarn J, Thaniyavarn S, Kameyama T, Haruki M, Imanaka T, Morikawa M, Kanaya S: Isolation and characterization of a halotolerant Bacillus subtilis BBK-1 which produces three kinds of lipopeptides: bacillomycin L, plipastatin, and surfactin. Extremophiles 2002, 6:499-506

51. Rahman KSM, Rahman TJ, McClean S, Marchant R, Banat IM: Rhamnolipid biosurfactant production by strains of Pseudomonas aeruginosa using low-cost raw materials. Biotechnol Prog 2002, 18:1277-1281.

52. Cooper DG, Macdonald CR, Duff JB, Kosaric N: Enhanced production of Surfactin from Bacillus subtilis by continuous product removal and metal cation additions. Appl Environ Microbiol 1981, 42:408-412. 
53. Javaheri M, Jenneman GE, McInerney MJ, Knapp RM: Anaerobic production of a biosurfactant by Bacillus licheniformis JF-2. App Environ Microbiol 1985, 50:698-700.

54. Yakimov MM, Timmis KN, Wray V, Fredrickson HL: Characterization of a new lipopeptide surfactant produced by thermotolerant and halotolerant subsurface Bacillus licheniformis BAS50. Appl Environ Microbiol 1995, 61:1705-1713.

55. Michel G, Sandrin C, Peypoux F: Coproduction of surfactin and Iturin A, lipopeptides with surfactant and antifungal properties, by Bacillus subtilis. Biotechnol Appl Biochem 1990, 12:370-375.

56. Reddy $P G$, Singh $H D$, Pathak MG, Bhagat SD, Baruah JN: Isolation and functional characterization of hydrocarbon emulsifying and solubilizing factors produced by a Pseudomonas species. Biotech. Bioengg 1983, 25:387-401.

57. Rosenberg EGA, Rosenberg M: Inhibition of bacterial adherence to hydrocarbons and epithelial cells by emulsan. Infect Immun 1983, 39:1024-1028.

58. Rosenberg E, Zuckerberg A, Rubinovitz C, Gutnick DL: Emulsifier of Arthrobacter RAG-1: isolation and emulsifying properties. Appl Environ Microbiol 1979, 37:402-408.

doi:10.1186/1475-2859-10-49

Cite this article as: Sekhon et al:: Enhanced biosurfactant production through cloning of three genes and role of esterase in biosurfactant release. Microbial Cell Factories 2011 10:49.

\section{Submit your next manuscript to BioMed Central and take full advantage of:}

- Convenient online submission

- Thorough peer review

- No space constraints or color figure charges

- Immediate publication on acceptance

- Inclusion in PubMed, CAS, Scopus and Google Scholar

- Research which is freely available for redistribution

Submit your manuscript at www.biomedcentral.com/submit 